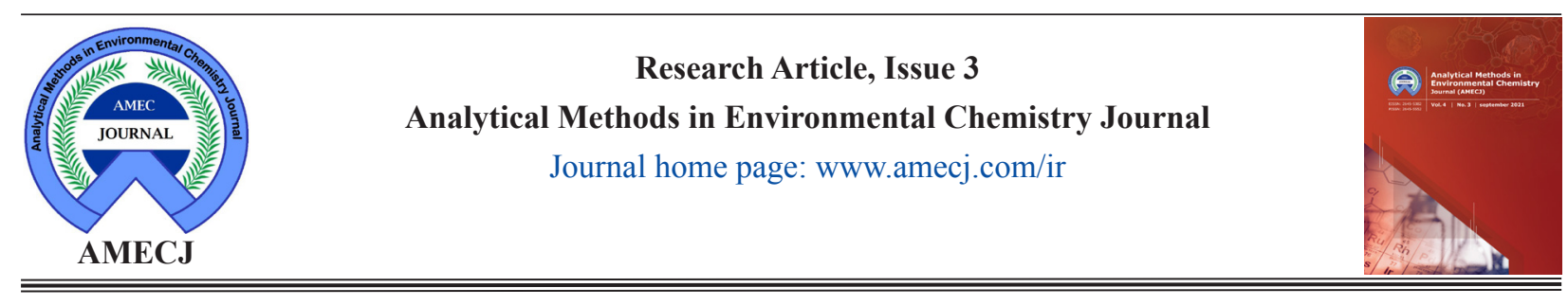

\title{
Thallium extraction in urine and water samples by nanomagnetic 4-Aminothieno[2,3-d] pyrimidine-2-thiol functionalized on graphene oxide
}

\author{
Seyed Jamilaldin Fatemi a,*, Mohammad Reza Akhgar ${ }^{\mathrm{b}}$ and Masoud Khaleghi Abbasabadi ${ }^{\mathrm{c}}$ \\ a Department of Chemistry, Shahid Bahonar University of Kerman, 133 -76169, Kerman, Iran \\ ${ }^{\mathrm{b}}$ Department of Chemistry, Faculty of Science, Kerman Branch, Islamic Azad University, Kerman, Iran \\ ${ }^{\mathrm{C}}$ Researcher in Nano Technology Center, Research Institute of Petroleum Industry (RIPI), P.O. Box 1998-14665, Tehran, Iran
}

A R T I C L E I N F O :

Received 20 May 2021

Revised form 18 Jul 2021

Accepted 13 Aug 2021

Available online 28 Sep 2021

Keywords:

Thallium,

Water and urine,

Nanomagnetic 4-Aminothieno[2,3-d] pyrimidine-2-thiol functionalized on graphene oxide,

Dispersive magnetic micro solid-phase extraction

\begin{abstract}
A B S T R A C T
Thallium is a water-soluble metal and extra dosage has toxicological effect in human body. Thallium is readily absorbed by inhalation, ingestion and skin contact. The symptomatology of thallium toxicity was seen in patients with hemorrhage, bone/gastrointestinal problems, delirium, convulsions and coma. So, accurate determination of thallium in water and human urine is necessary. In this research, a novel and applied method based on $25 \mathrm{mg}$ of nanomagnetic 4-Aminothieno[2,3-d] pyrimidine-2-thiol functionalized on graphene oxide $\left(\mathrm{Fe}_{3} \mathrm{O}_{4}\right.$-ATPyHS@GO) was used for thallium extraction in 50 $\mathrm{mL}$ of water, wastewater and urine samples by dispersive magnetic micro solid-phase extraction (DM- $\mu-\mathrm{SPE})$. After extraction and back-extraction of solid phase by $1 \mathrm{~mL}$ of nitric acid solution, the concentration of thallium ions determined by flame atomic absorption spectrometry (F-AAS). The working/linear range, the limit of detection (LOD), and preconcentration factor (PF) were achieved (4-1400 $\mu \mathrm{g}$ $\mathrm{L}^{-1}$; 4-300 $\mu \mathrm{g} \mathrm{L}^{-1}$ ), $0.9 \mu \mathrm{g} \mathrm{L}^{-1}$, and 50, respectively (Mean RSD $\%=1.8$ water; 2.1 urine). The absorption capacity of GO and $\mathrm{Fe}_{3} \mathrm{O}_{4}$-ATPyHS@ GO adsorbent were achieved $7.2 \mathrm{mg} \mathrm{g}^{-1}$ and $137.5 \mathrm{mg} \mathrm{g}^{-1}$ for $5 \mathrm{mg}$ $\mathrm{L}^{-1}$ of thallium, respectively. The procedure was validated by ICP-MS analyzer.
\end{abstract}

\section{Introduction}

The Thallium use as in semiconductor and optical industries. The concentration of thallium in rocks and soil (limestone, granite) ranges between $0.05-1.7 \mathrm{mg} \mathrm{kg}^{-1}$ and $1.7-55$ $\mathrm{mg} \mathrm{kg}^{-1}$, respectively [1]. The organic slates and carbon source have $1000 \mathrm{mg} \mathrm{kg}^{-1}$ thallium [2], and high concentration of thallium exist sulfur salts of thallium [3]. Contamination with thallium is effected on the environmental and

*Corresponding Author: Seyed Jamilaldin Fatemi

Email: fatemijam@uk.ac.ir

https://doi.org/10.24200/amecj.v4.i03.150 human health. Thallium has toxic effect even at sub ppb concentration and accumulate in plant, vegetables, fruit, microorganisms, animals and human tissues due to water soluble $[4,5]$. The occupational exposure of thallium is $0.1 \mathrm{mg} \mathrm{m}^{-2}$ for skin and more than $15 \mathrm{mg} \mathrm{m}^{-2}$ is dangerous for human. Thallium can be absorbed from inhalation, ingestion and skin. So, the thallium toxicity must be evaluated in patients through determination in water, wastewater, urine, hair, nail and blood samples. The toxicity of this element is higher compared to mercury, cadmium and lead $[6,7]$. The mean daily diet contains $2 \mathrm{ng} \mathrm{L}^{-1}$ thallium 
and the average content of thallium in the human body was $0.1 \mathrm{mg}$. The concentrations in blood is less than $3 \mu \mathrm{g} \mathrm{L}^{-1}$ and due to reference values thallium has low concentration between $0.15-0.6$ $\mu \mathrm{g} \mathrm{L}^{-1}$ in blood and $0.02-0.3 \mu \mathrm{g} \mathrm{L}^{-1}$ in serum $[8,9]$. Groesslova and Wojtkowiak showed that the toxicity of thallium is mainly related to the similarity between $\mathrm{Tl}$ (I) ions and $\mathrm{K}$ ions, which cause to the thallium interference with potassium and disorder of potassiumassociated metabolic processes. Also, thallium disrupts the disulfide bonds and cysteine cross-linking and cause to the keratin reduction $[10,11]$. The thallium-201, a radioactive isotope, was used for evaluating coronary artery disease. This type of thallium is more than 4000 times less potent. Thallium-201 is useful in distinguishing toxoplasmosis from Primary CNS lymphoma (PCNSL)in HIV patients. Also, the thallium-201 scintigraphy is useful to diagnose the Kaposi sarcoma, the thyroid imaging and various tumors of the lungs [12]. the acute thallium toxicity has been reported between $6-15 \%$ in humans by health organization and the dosage from 10 to $15 \mathrm{mg}$ $\mathrm{kg}^{-1}$ is a lethal dose for humans. Elimination phase for thallium stats about 24 hours' post-exposure and is mainly achieved through renal excretion and the elimination phase may take up to 30 days with long time. Symptoms of acute exposure of thallium are gastrointestinal, CNC problem, and skin [13,14]. The chronic exposure is gastrointestinal symptoms include, the abdominal pain, the vomiting and the diarrhea. Therefore, due to adverse effect of thallium in human health, the determination human urine, foods and waters must be considered [15]. Based on the thallium toxicity, the power technique must be used for determining of thallium in environmental (water) and human biological (urine) samples. Numerous papers showed that the measurement of this topic with different analytical methods in various matrixes such as, the laser excited atomic fluorescence spectrometry (LE-AFS) [16], the anodic stripping voltammetry (ASV) [17], the inductively coupled plasma optical emission spectrometry (ICP-OES) [18], the flame atomic absorption spectrometry (FAAS) [19], the electrothermal atomic absorption spectrometry (ET-AAS) [19] and the high resolution inductively coupled plasma mass spectrometry (HR-ICP-MS) [20].

In this research, a novel method based on nanomagnetic 4-Aminothieno[2,3-d] pyrimidine2-thiol functionalized on graphene oxide as a $\mathrm{Fe}_{3} \mathrm{O}_{4}$-ATPyHS@GO adsorbent was used for the extraction of thallium in the water, wastewater and the urine samples. The thallium concentration was determined based on dispersive magnetic micro solid-phase extraction by F-AAS.

\section{Experimental}

\subsection{Apparatus and Characterization}

The thallium value was determined by flame atomic absorption spectrometer coupled (F-AAS, Varian, USA). The Air-acetylene $\left(\mathrm{C}_{2} \mathrm{H}_{2}\right)$ and the deuterium lampas was adjusted The limit of detection (LOD) and sensitivity of F-AAS obtained $0.2 \mathrm{mg} \mathrm{L}^{-1}$ and $0.15 \mathrm{mg} \mathrm{L}^{-1}$. The HCL of Tl was adjusted based on catalog book with wavelength of $276.8 \mathrm{~nm}$, slit of $0.5 \mathrm{~nm}$ and current of $10 \mathrm{~mA}$. All samples injected to F-AAS by auto- injector $(0.5-3 \mathrm{~mL})$. The working range and linear range of AT-AAS were obtained 0.2-75 $\mathrm{mg} \mathrm{L}^{-1}$ and 0.2- $15 \mathrm{mg} \mathrm{L}^{-1}$, respectively. The electrothermal atomic absorption spectrophotometer (ET-AAS, Varian, USA) was used for validation of thallium in urine and water samples. For suppress of ionization in F-AAS, the reagent of $\mathrm{KNO}_{3}$ or $\mathrm{KCl}$ was used as a $2000 \mathrm{mg} \mathrm{L}^{-1}$ of $\mathrm{K}$ in final solution. The $\mathrm{pH}$ was calculated by digital $\mathrm{pH}$ meter (Metrohm 744 , Swiss). The different buffer of the acetate ( $\mathrm{PH}$ 3-6) were used for adjusting $\mathrm{pH}$. The ultra-sonication (Grant, U.K) and the Sigma 3K30 magnetic centrifuge (30.000 rpm, UK) was used. The natural flake graphite (325 mesh, 99.95\%), were purchased from Merck chemical Company. The Perkin Elmer Spectrum spectrophotometer (65 FT-IR, USA) was used for FT-IR spectra. The PRO X-ray diffractometer was used for The XRD spectra. The images of field emission scanning electron microscope (FE-SEM) were prepared by SEM of Tescan Mira-3. 


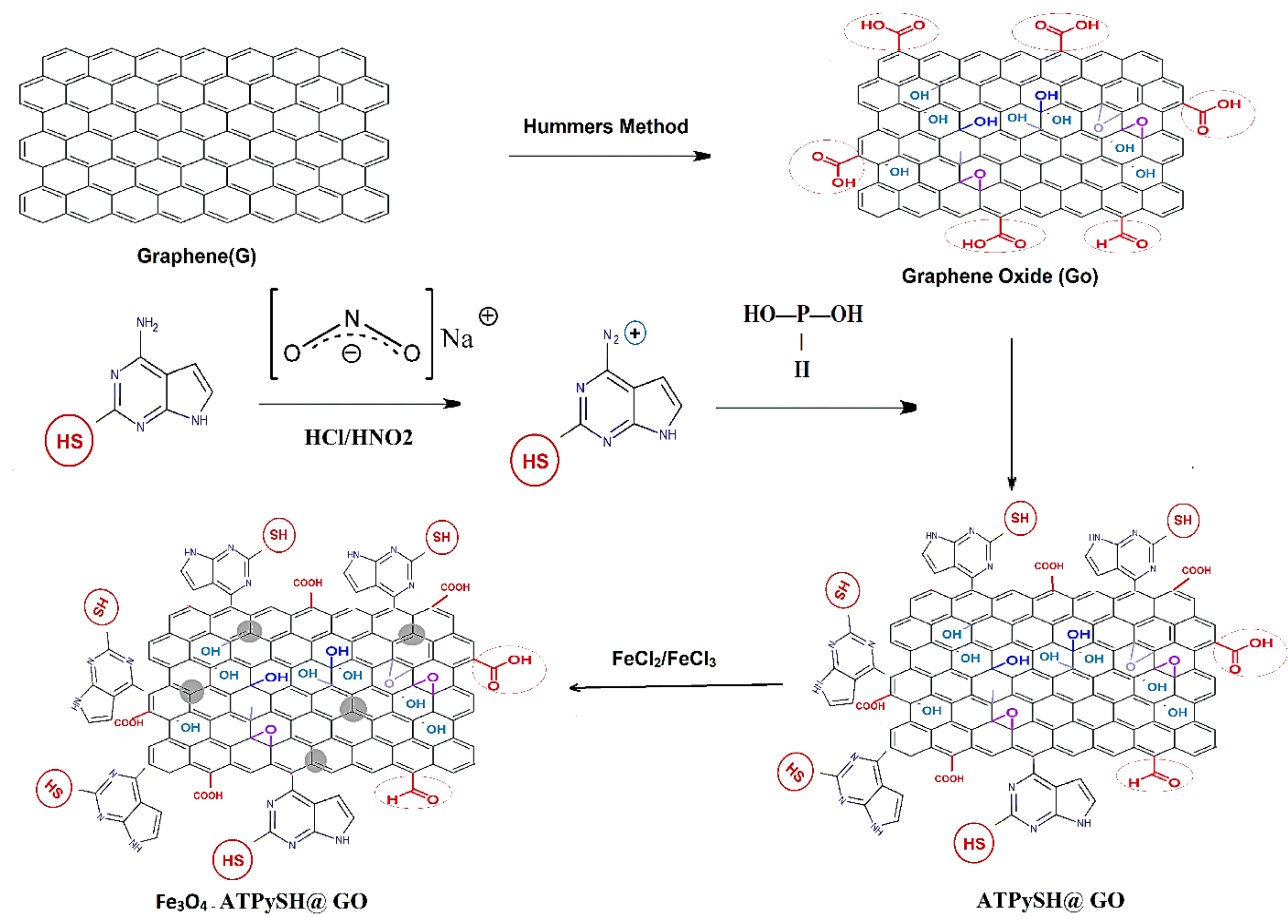

Fig.1. Synthesis of nanomagnetic ATPyHS@GO adsorbent by 4-aminothieno[2,3-d] pyrimidine-2-thioland and $\mathrm{Fe}_{3} \mathrm{O}_{4}$ on $\mathrm{GO}[22-24]$

\subsection{Materials}

All reagents with analytical grade such as; the thallium solution $\left(\mathrm{Tl} \mathrm{NO}_{3}\right.$ ), the acids and base solutions $\left(\mathrm{HNO}_{3}, \mathrm{HCl}, \mathrm{NaOH}\right)$ were purchased from sigma Aldrich (Germany). The standard solution of thallium nitrate (CAS N: 10102-45-1, Sigma, Germany) was prepared from stock of 1000 mg L ${ }^{-1}$ solution in $1 \% \mathrm{HNO}_{3}$ for further studies. The standard solutions for calibration were daily prepared by distilled water (DW) from Millipore (USA). The other reagents such as acetone and ethanol with analytical grade were purchased from Merck (Germany). The citric acid was used for phosphate citrate buffer for $\mathrm{PH}$ between 2.1-7.4 and the acetate buffer was used for $\mathrm{pH}$ from 2.8 to 6.2 which was purchased from Merck.

\subsection{Synthesis of $\mathrm{Fe}_{3} \mathrm{O}_{4}-A T P y H S @ G O$}

The GO was prepared following the modified Hummers method. $5 \mathrm{~g}$ of graphite powder was mixed with $250 \mathrm{~mL}$ of $\mathrm{H}_{2} \mathrm{SO}_{4}$ and stirred for 24 h. Then, $30 \mathrm{~g}$ of $\mathrm{KMnO}_{4}$ was gradually added to the mixture based on stirring at $50{ }^{\circ} \mathrm{C}$ [21]. Due to previous studies, 4-aminothieno[2,3-d] pyrimidine- 2-thiol $(10 \mathrm{~g})$ was added to $150 \mathrm{~mL}$ of ethanol and DW $(1: 1 \mathrm{v} / \mathrm{v})$. Then, $180 \mathrm{mg}$ of GO was added to the resulted solution at $35^{\circ} \mathrm{C}$. The $\mathrm{H}_{3} \mathrm{PO}_{2}(50 \mathrm{~mL}, 50$ $w t \%$ ) was added to product and stirred for $90 \mathrm{~min}$. The product of ATPyHS@GO was washed and dried by DW and oven, respectively. The magnetic nanostructure was prepared by co-precipitation of $\mathrm{FeCl}_{2} \cdot 4 \mathrm{H}_{2} \mathrm{O}$ and $\mathrm{FeCl}_{3} \cdot 6 \mathrm{H}_{2} \mathrm{O}$, in the presence of 4-Aminothieno[2,3-d] pyrimidine-2-thiol graft on GO (ATPyHS@GO). First, the mixture of $\mathrm{FeCl}_{2} \cdot 4 \mathrm{H}_{2} \mathrm{O}$ and $\mathrm{FeCl}_{3} \cdot 6 \mathrm{H}_{2} \mathrm{O}$ was prepared with a molar ratio of 1:2. For synthesis nanomagnetic adsorbent, $10 \mathrm{mg}$ of 4-aminothieno[2,3-d] pyrimidine-2-thiol grafted on graphene oxide (ATPyHS@GO) was solved to $10 \mathrm{~mL}$ of DW and sonicated for $40 \mathrm{~min}$. Then $125 \mathrm{mg}$ of $\mathrm{FeCl}_{2} \cdot 4 \mathrm{H}_{2} \mathrm{O}$ and $200 \mathrm{mg}$ of $\mathrm{FeCl}_{3} \cdot 6 \mathrm{H}_{2} \mathrm{O}$ in $10 \mathrm{~mL}$ of deionized water were added to remain solution at $25^{\circ} \mathrm{C}$. For adjusting of $\mathrm{pH}=11$, the ammonia solution was added at $65^{\circ} \mathrm{C}$. After 20 min stirring, the product was cooled at $25^{\circ} \mathrm{C}$. Finally, the black $\mathrm{Fe}_{3} \mathrm{O}_{4}$ ATPyHS@GO was centrifuged at 4000 rpm for 50 min, washed for 10 times (DW) and dried at $70{ }^{\circ} \mathrm{C}$ based on vacuum accessory [22-24]. 


\subsection{Extraction Procedure}

By the DM- $\mu$-SPE procedure, $50 \mathrm{~mL}$ of water and standard samples $\left(4-300 \mu \mathrm{g} \mathrm{L}^{-1}\right)$ were used for separation and determination of thallium ions at pH 4-6. Firstly, 25 mg of $\mathrm{Fe}_{3} \mathrm{O}_{4}$-ATPyHS@ GO added to water, urine and thallium standard solution and the sample sonicated for $3.0 \mathrm{~min}$ at $\mathrm{pH}=5$. After sonication, the $\mathrm{Tl}$ ions was chemically absorbed on thiol groups (ATPyHS) of $\mathrm{Fe}_{3} \mathrm{O}_{4}-$ ATPyHS@GO adsorbent (Tl+......:SH-ATPy@ GO) and then, settled down in bottom of magnetic centrifuge conical tube. Then, the thallium ions were back-extracted from $\mathrm{Fe}_{3} \mathrm{O}_{4}$-ATPyHS@
$\mathrm{GO}$ at basic $\mathrm{pH}$ with $\mathrm{NaOH}$ solution $(0.1 \mathrm{M}, 0.5$ $\mathrm{mL}$ ) and was simply separated by the external magnetic accessory. Finally, the remain solution was determined by FAAS after dilution with DW up to $1 \mathrm{~mL}$ (Fig.2). The procedure was round for a blank solution without thallium ions for ten times. The analytical parameters showed in Table 1. The recovery of thallium extraction was calculated by the equation 1 . The $C_{i}$ and $C_{f}$ are the primary and final concentration of thallium, which was determined by F-AAS $(n=10)$.

$$
\text { Recovery }(\%)=\left(\mathrm{C}_{\mathrm{i}}-\mathrm{C}_{\mathrm{f}}\right) / \mathrm{C}_{\mathrm{i}} \times 100 \quad(\text { Eq. } 1)
$$

Table 1. The analytical parameters for determination thallium in water and urine samples based on $\mathrm{Fe}_{3} \mathrm{O}_{4^{-}}$ ATPyHS@GO adsorbent by the DM- $\mu$-SPE procedure

\begin{tabular}{ll}
\hline Parameters & Values \\
\hline Working $\mathrm{pH}$ & $4-6$ \\
Amount of $\mathrm{Fe}_{3} \mathrm{O}_{4}$-ATPyHS@GO adsorbent $(\mathrm{mg})$ & 25 \\
Sample volume of water $(\mathrm{mL})$ & 50 \\
Volume of sample injection & $1.0 \mathrm{~mL}$ \\
Linear range for water & $4.0-300 \mu \mathrm{g} \mathrm{L}^{-1}$ \\
working range for water & $4.0-1400 \mu \mathrm{g} \mathrm{L}^{-1}$ \\
Mean RSD \%, $\mathrm{n}=10$ & 1.8 \\
LOD for water & $0.9 \mu \mathrm{g} \mathrm{L}^{-1}$ \\
Preconcentration factor & 50 \\
Volume and concentration of $\mathrm{NaOH}$ & $0.5 \mathrm{~mL}, 0.4 \mathrm{M}$ \\
Shaking time & $3.0 \mathrm{~min}$ \\
Correlation coefficient & $\mathrm{R}^{2}=0.9997$ \\
\hline
\end{tabular}

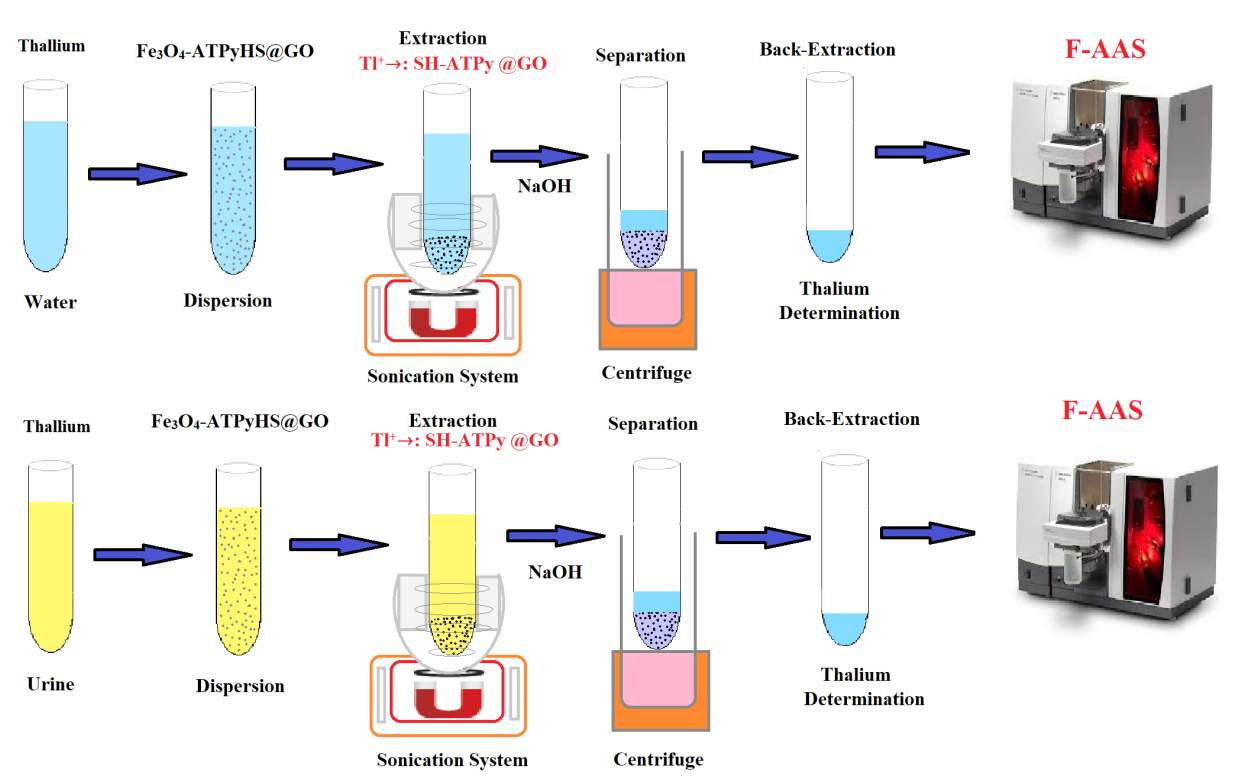

Fig.2. The extraction procedure of thallium in water and urine samples based on $\mathrm{Fe}_{3} \mathrm{O}_{4}$-ATPyHS@GO adsorbent by the DM- $\mu$-SPE procedure 


\section{Results and Discussion}

\subsection{TEM Spectra}

The TEM of $\mathrm{Fe}_{3} \mathrm{O}_{4}$-ATPyHS@GO and GO adsorbent was prepared (Fig. 3a and 3b). Based on the TEM images, both of $\mathrm{GO}$ and $\mathrm{Fe}_{3} \mathrm{O}_{4}$-ATPyHS@ GO have the thin sheets about 30-80 nm. The $\mathrm{Fe}_{3} \mathrm{O}_{4}$ was seen as black point on surface of GO in TEM of $\mathrm{Fe}_{3} \mathrm{O}_{4}$-ATPyHS@GO adsorbent (Fig. 3a).

\subsection{FE-SEM Spectra}

The morphology of $\mathrm{Fe}_{3} \mathrm{O}_{4}$-ATPyHS@GO and GO adsorbent is prepared by the field emission scanning electron microscopy (FE-SEM) (Fig. 4a and 4b).

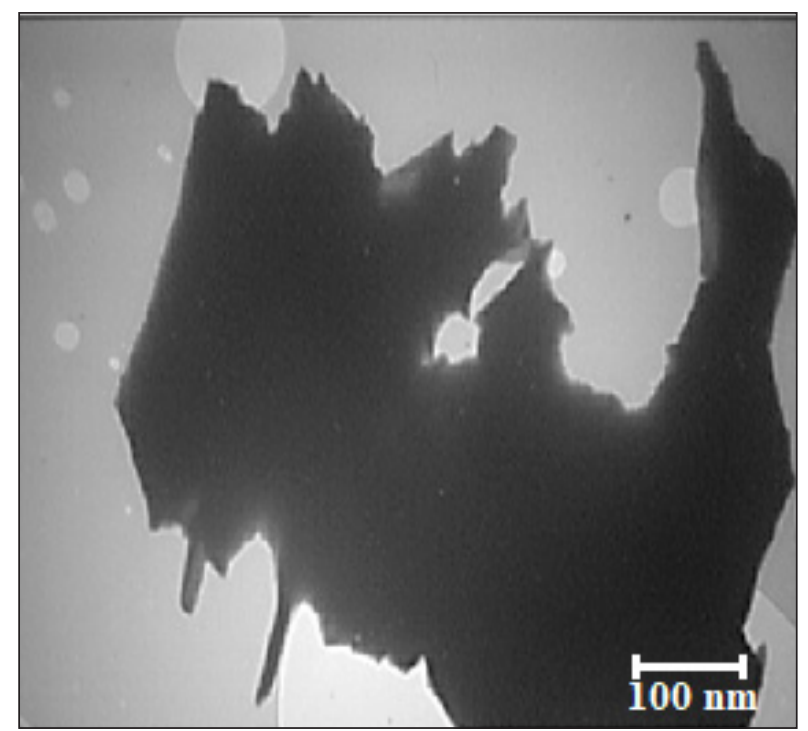

Fig. 3a. TEM of the $\mathrm{Fe}_{3} \mathrm{O}_{4}$-ATPyHS@GO

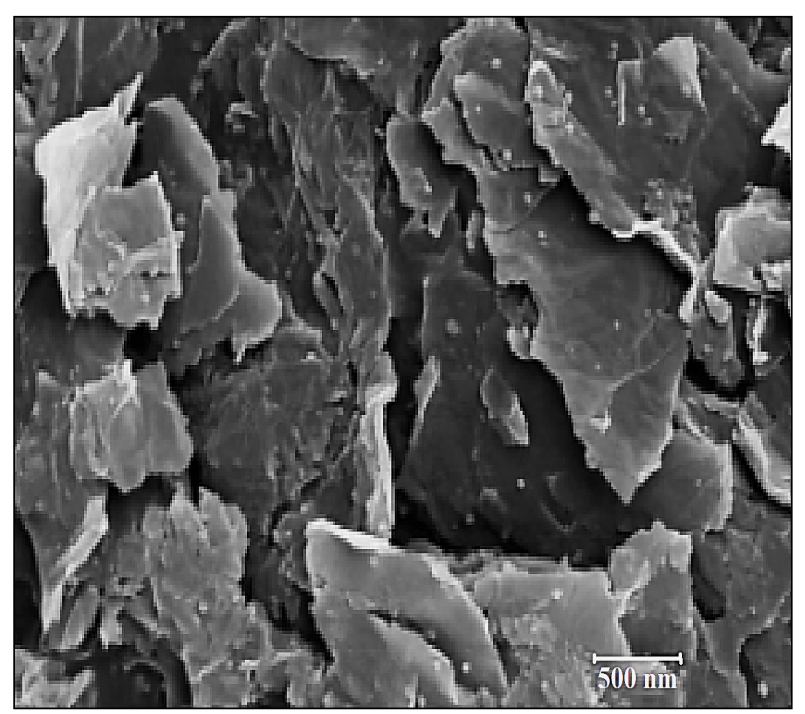

Fig. 4a. FE-SEM of the $\mathrm{Fe}_{3} \mathrm{O}_{4}$-ATPyHS@GO
Based on the SEM images, both of $\mathrm{GO}$ and $\mathrm{Fe}_{3} \mathrm{O}_{4}-$ ATPyHS@GO have the thin sheets nearly related to each other. The SEM images of GO and $\mathrm{Fe}_{3} \mathrm{O}_{4} @ 4$ PhMT-GO showed us, the HS and $\mathrm{Fe}_{3} \mathrm{O}_{4}$ had no effect on the morphology of the GO sheets. Also, the nanoparticles of $\mathrm{Fe}_{3} \mathrm{O}_{4}$ have a spherical morphology on HS-GO with a diameter of $40 \mathrm{~nm}$.

\subsection{FTIR diagram}

The infrared spectra of pure $\mathrm{GO}$ and $\mathrm{Fe}_{3} \mathrm{O}_{4}-$ ATPyHS@GO are presented in Figure 5. The spectra of GO and $\mathrm{Fe}_{3} \mathrm{O}_{4}$-ATPyHS@GO are showed to the stretching bands of $(\mathrm{O}-\mathrm{H}$;

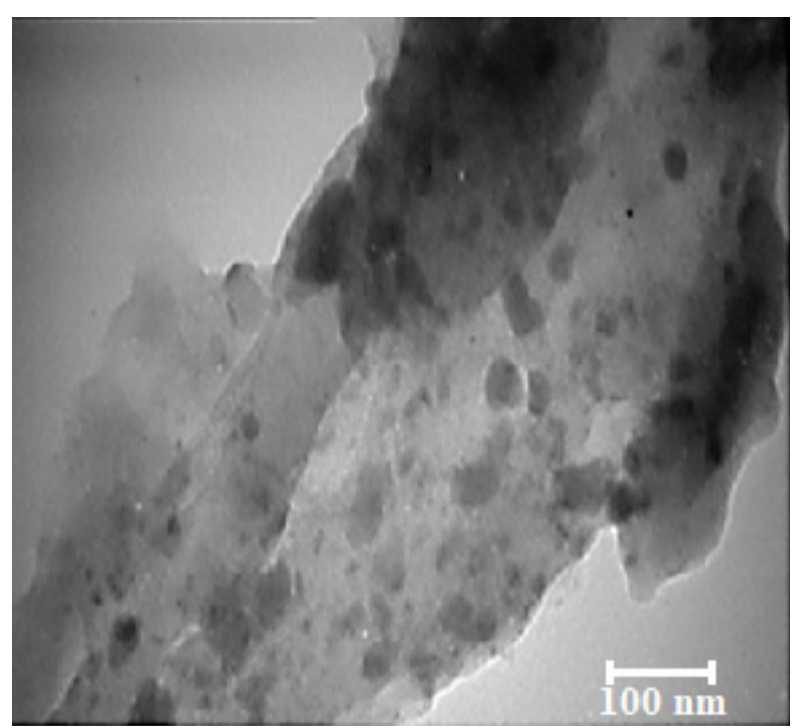

Fig. 3b. TEM of the GO adsorbent

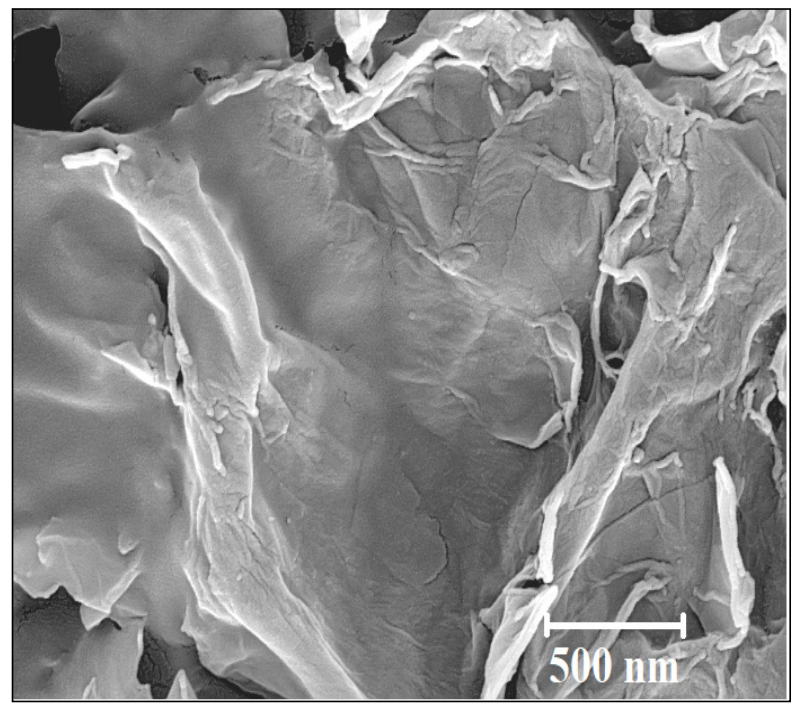

Fig. 4b. FE-SEM of the GO 


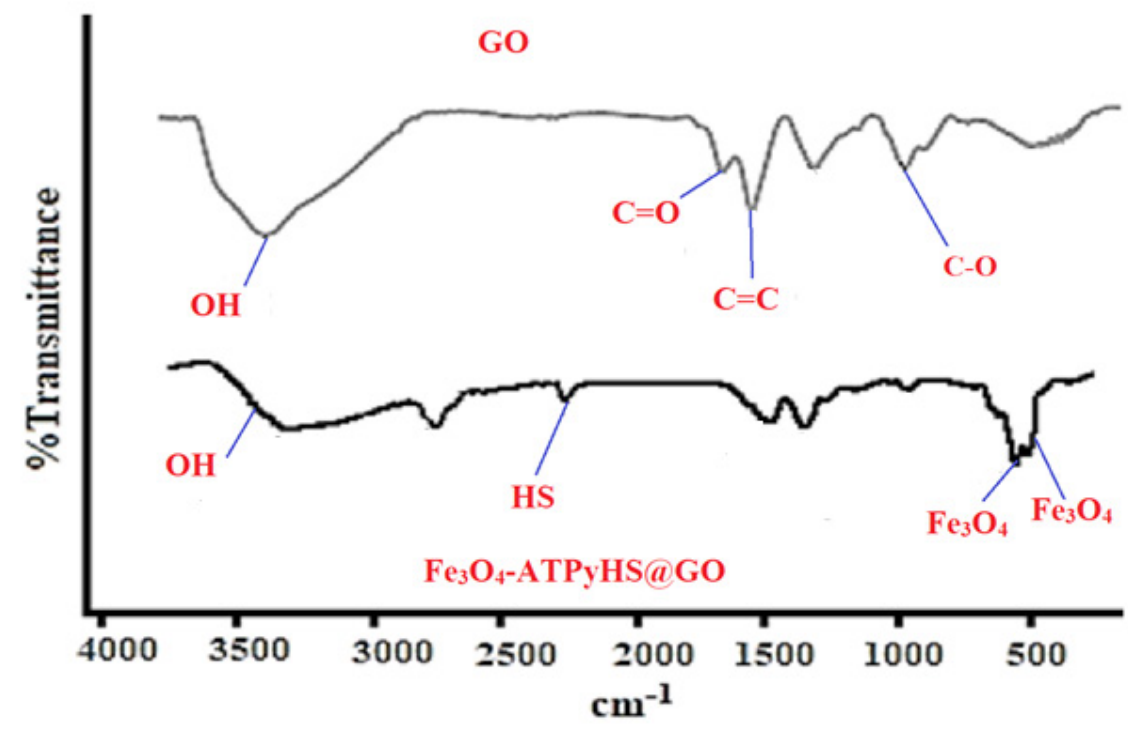

Fig. 5. The FTIR spectra of pure GO and $\mathrm{Fe}_{3} \mathrm{O}_{4}$-ATPyHS@GO adsorbents

3415), $(\mathrm{C}=\mathrm{O} ; 1730),(\mathrm{C}=\mathrm{C} ; 1624)$, and $(\mathrm{C}-\mathrm{O}$; 1061). Also, the peak of FTIR at range of 2600$3500 \mathrm{~cm}^{-1}$ belong to to the $\mathrm{O}-\mathrm{H}$ and $\mathrm{C}=\mathrm{C}(\mathrm{OH})$ function. Moreover, the peak of $1400 \mathrm{~cm}^{-1}$ and $2234 \mathrm{~cm}^{-1}$ related to tertiary hydroxyl groups $(\mathrm{OH})$ and HS function on GO. In -addition the peaks at $628 \mathrm{~cm}^{-1}$ and $583 \mathrm{~cm}^{-1}$ belong to the Iron oxide [22-24].

\subsection{X-ray diffraction (XRD) patterns}

The X-ray diffraction patterns of $\mathrm{Fe}_{3} \mathrm{O}_{4}$-ATPyHS@ GO was shown in Figure 6. GO have a single original peak at $2 \theta=12^{\circ}$ which is related to the $\mathrm{O}_{2}$ groups. In both of GO and $\mathrm{Fe}_{3} \mathrm{O}_{4} @ 4$-PhMT-

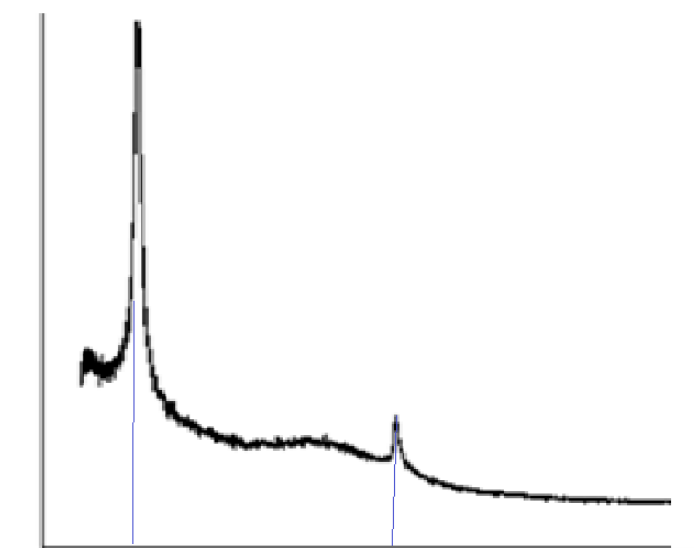

0.00010 .00020 .00030 .00040 .00050 .00060 .00070 .00080 .000

$2 \theta$
GO adsorbent, the XRD peaks were observed at $2 \theta=12^{\circ}$ and $41.58^{\circ}$ which are belonged to (002) and (100), respectively. Based on the XRD peak of $\mathrm{Fe}_{3} \mathrm{O}_{4}$-ATPyHS@GO, the intensity of the peak at $2 \theta=12^{\circ}$ has decreased due to function on GO with $\mathrm{HS}$ and $\mathrm{Fe}_{3} \mathrm{O}_{4}$. In addition, the peak at $2 \theta=12^{\circ}$ showed that the stability of $\mathrm{O}_{2}$ functionalities even after the functionalization of $\mathrm{GO}$ with $\mathrm{HS}$ or $\mathrm{Fe}_{3} \mathrm{O}_{4}$ groups. The similar XRD peak of $\mathrm{Fe}_{3} \mathrm{O}_{4}$ can be seen for the $\mathrm{Fe}_{3} \mathrm{O}_{4}$-ATPyHS@GO adsorbent which are confirmed to the cubic spinel crystal structure of $\mathrm{Fe}_{3} \mathrm{O}_{4}$. So, the functionalities of $\mathrm{HS}$ and $\mathrm{Fe}_{3} \mathrm{O}_{4}$ were successfully done without changing in structure of GO.

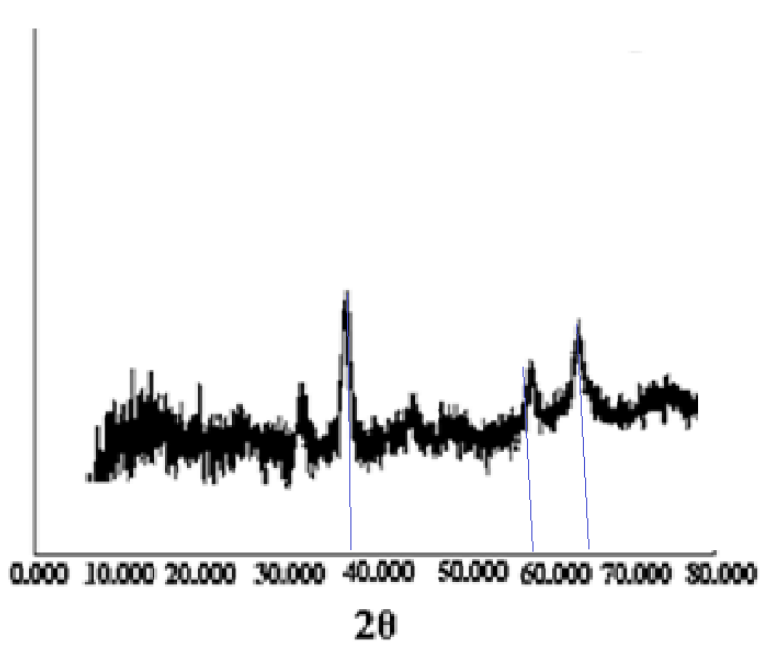

Fig. 6. XRD patterns of (a) $\mathrm{GO}$ adsorbent and (b) $\mathrm{Fe}_{3} \mathrm{O}_{4}$-ATPyHS@GO adsorbent [22] 


\subsection{Optimizing extraction parameters}

By DM- $\mu$-SPE procedure, the separation/extraction of thallium in water, wastewater and urine samples was achieved by a novel $\mathrm{Fe}_{3} \mathrm{O}_{4}$-ATPyHS@ GO adsorbent between 4-300 $\mu \mathrm{g} \mathrm{L}^{-1}$ thallium concentration. For the efficient extraction of thallium based on $\mathrm{Fe}_{3} \mathrm{O}_{4}$-ATPyHS@GO adsorbent, the extraction conditions must be optimized. So, the effective parameters such as $\mathrm{pH}$, the amount of adsorbent, the eluent, the sample volume, and the adsorption capacity must be studied.

\subsection{1. pH effect}

The $\mathrm{pH}$ of extraction of thallium in water and urine samples must be evaluated and optimized. The favorite $\mathrm{pH}$ cause to increase the adsorption of thallium ions by the $\mathrm{Fe}_{3} \mathrm{O}_{4}$-ATPyHS@GO adsorbent. So, the different $\mathrm{pH}$ between 2-11 was examined for thallium extraction in water and urine samples by adjusting $\mathrm{pH}$ with different buffer solutions. The results showed us, the maximum extraction of the $\mathrm{Fe}_{3} \mathrm{O}_{4}$-ATPyHS@GO adsorbent for $\mathrm{Tl}(\mathrm{I})$ was obtained at $\mathrm{pH}$ of 4-7. Also, the recoveries for thallium were decreased at acidic $\mathrm{pH}$ less than 4 and basic $\mathrm{pH}$ more than 7. So, the $\mathrm{pH} 5$ was selected as the optimal $\mathrm{pH}$ for extraction of thallium in water and urine samples by the $\mathrm{Fe}_{3} \mathrm{O}_{4}$-ATPyHS@ GO adsorbent (Fig.7). The mechanism of extraction of thallium was occurred by the dative bond of thiol group $\left[2\left(\mathrm{Ti}^{+}\right) \ldots \ldots .^{2}: \mathrm{SH}-\mathrm{ATPyHS} @ \mathrm{GO}-\mathrm{Fe}_{3} \mathrm{O}_{4}\right)$ with the positively charged of thallium $\left(\mathrm{Tl}^{+}\right)$at optimized $\mathrm{pH}$. In addition, the thallium ions participated $(\mathrm{Tl}(\mathrm{OH}))$ at more than $\mathrm{pH}$ 7.5.

\subsubsection{Amount of $\mathrm{Fe}_{3} \mathrm{O}_{4}-A T P y H S @ G O$ adsorbent} Foe high extraction of thallium in water/urine samples, the amount of the $\mathrm{Fe}_{3} \mathrm{O}_{4}$-ATPyHS@ GO adsorbent evaluated at thallium concentration between 4-300 $\mu \mathrm{g} \mathrm{L}^{-1}$. For this purpose, the various amount of the $\mathrm{Fe}_{3} \mathrm{O}_{4}$-ATPyHS@GO adsorbent between 5-50 mg were studied for $\mathrm{Tl}(\mathrm{I})$ extraction in water and standard solutions by the DM- $\mu$-SPE method. As Figure 8, the best recovery for thallium extraction was created by $20 \mathrm{mg}$ of $\mathrm{Fe}_{3} \mathrm{O}_{4}$-ATPyHS@ GO adsorbent. So, $25 \mathrm{mg}$ of the $\mathrm{Fe}_{3} \mathrm{O}_{4}$-ATPyHS@ $\mathrm{GO}$ adsorbent was used for further work.

\subsubsection{Effect of eluents}

The various eluents such as $\mathrm{HNO}_{3}, \mathrm{H}_{2} \mathrm{SO}_{4}, \mathrm{NaOH}$ and $\mathrm{CH}_{3} \mathrm{COOH}$ were used for back extraction thallium ions from the $\mathrm{Fe}_{3} \mathrm{O}_{4}$-ATPyHS@GO adsorbent. In acidic and basic $\mathrm{pH}$, the dative bonding between the thiol group (HS) and thallium (Tl) was started to dissociate $(4>\mathrm{pH}>6)$. So, after break down the bonging, the thallium ions released in eluent solution by elution. At $\mathrm{pH}$ more than 7 , the thallium participated as thallium hydroxyl (Tl-OH)

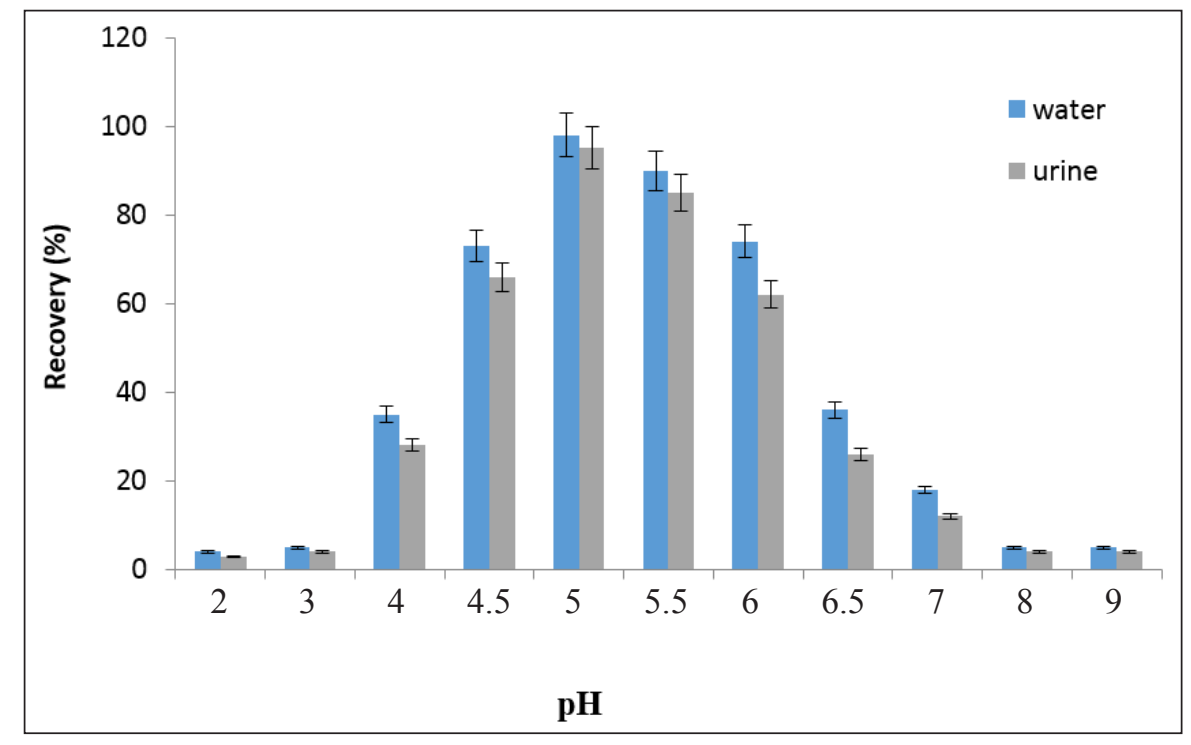

Fig.7. The effect of $\mathrm{pH}$ on thallium extraction in water and urine samples by $\mathrm{Fe}_{3} \mathrm{O}_{4}$-ATPyHS@GO adsorbent 


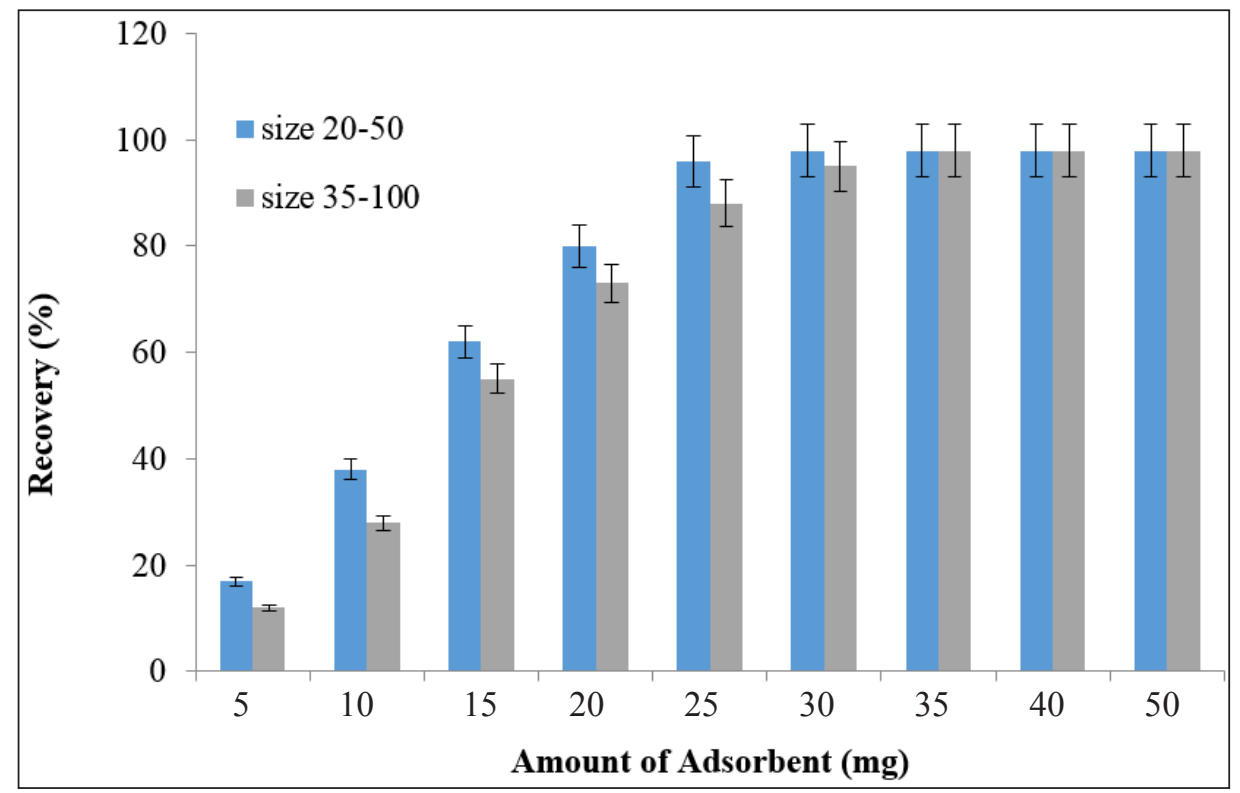

Fig.8. The effect of amount of $\mathrm{Fe}_{3} \mathrm{O}_{4}$-ATPyHS@GO adsorbent on thallium extraction in water and urine samples by the DM- $\mu-\mathrm{SPE}$ method

and in low $\mathrm{pH}$, the bonding of Tl-SH dissociated. Due to results, the $\mathrm{HNO}_{3}$ and $\mathrm{NaOH}$ has more recovery as compared to $\mathrm{H}_{2} \mathrm{SO}_{4}$ and $\mathrm{CH}_{3} \mathrm{COOH}$. The different acid solution with different volume and concentration was used for back extraction Tl(I) in water and urine samples $\left(0.2-2.0 \mathrm{~mol} \mathrm{~L}^{-1}, 0.1-0.5\right.$ $\mathrm{mL}$ ) by the DM- $\mu$-SPE procedure. Due to results, the $\mathrm{Tl}$ ions were completely back-extracted from the $\mathrm{Fe}_{3} \mathrm{O}_{4}$-ATPyHS@GO adsorbent by nitric acid and
$\mathrm{NaOH}$ solutions more than $1.0 \mathrm{~mol} \mathrm{~L}^{-1}$ and $0.1 \mathrm{~mol}$ $\mathrm{L}^{-1}$, respectively. Therefore, $0.1 \mathrm{~mol} \mathrm{~L}^{-1}$ of $\mathrm{NaOH}$ was used as an optimum eluent for this study. Also, the effect of different volumes of eluents from 0.1 $\mathrm{mL}$ to $0.5 \mathrm{~mL}$ for thallium was checked. Therefore, $0.5 \mathrm{~mL}$ of $\mathrm{NaOH}(0.1 \mathrm{M})$ selected as optimum elution (Fig. 9). Also, the more concentration of $\mathrm{NaOH}(\mathrm{M}>0.2)$ caused to the thallium participation (Tl-OH).

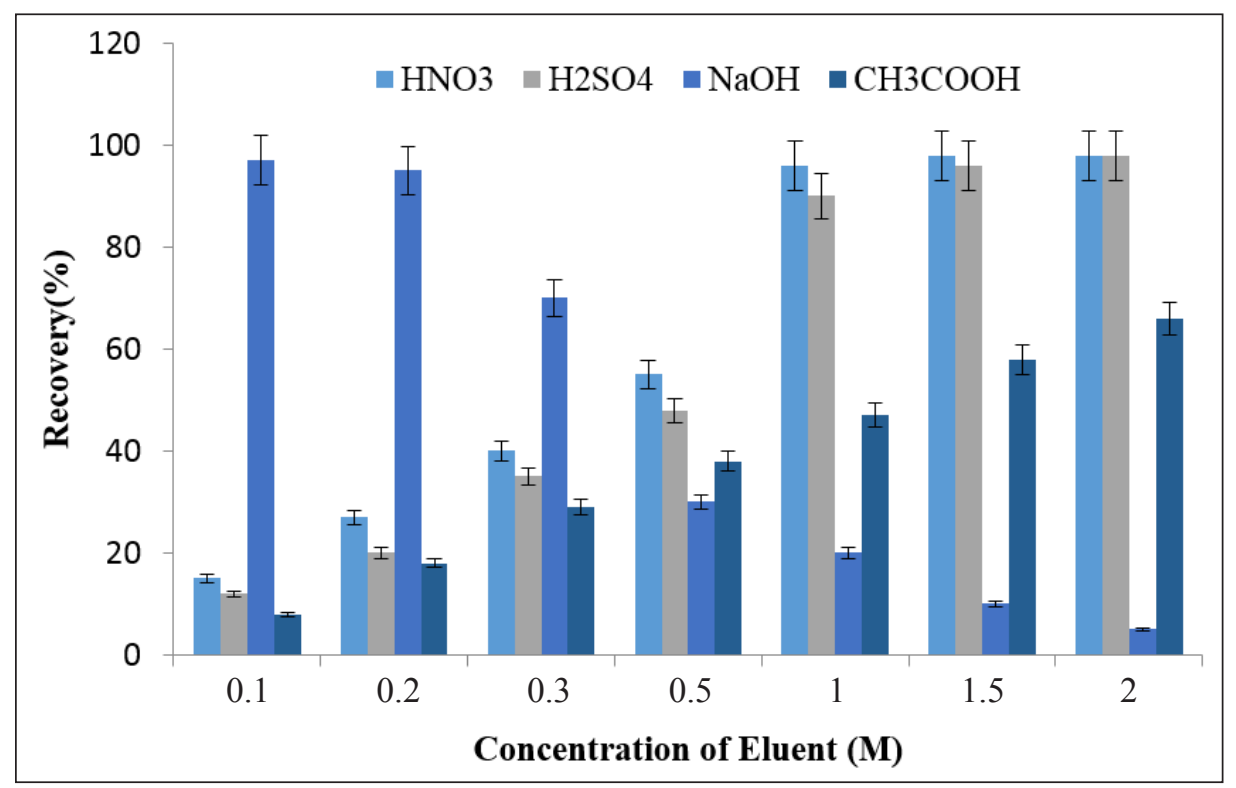

Fig.9. The effect of eluent concentration on thallium extraction in water and urine samples by the $\mathrm{Fe}_{3} \mathrm{O}_{4}$-ATPyHS@GO adsorbent 


\subsubsection{Effect of sample volume}

The main factor for efficient extraction of Tl ions from water/urine samples is sample volume. The effect of different volumes between 10-200 $\mathrm{mL}$ for Tl extraction based on the $\mathrm{Fe}_{3} \mathrm{O}_{4}$-ATPyHS@GO adsorbent was studied and optimized in water and urine samples (4$300 \mu \mathrm{g} \mathrm{L}^{-1}$ ). By results, the high recovery (\%) was occurred for $55 \mathrm{~mL}$ for urine and $70 \mathrm{~mL}$ for water samples. So, $50 \mathrm{~mL}$ of sample volume was used for further work by the DM- $\mu$-SPE procedure (Fig. 10).

\subsubsection{Effect of sonication time}

The dispersion of $\mathrm{Fe}_{3} \mathrm{O}_{4}$-ATPyHS@GO adsorbent increased the interaction between thiol group (HS) and thalliumionsatpH5. By uniform dispersion of the $\mathrm{Fe}_{3} \mathrm{O}_{4}$ ATPyHS@GO adsorbent, the chemical adsorption of thallium occurred. Therefore, the extraction recovery increased due to physical adsorption of GO and chemical bonding of $\mathrm{HS}$ group in $\mathrm{Fe}_{3} \mathrm{O}_{4}$-ATPyHS@GO adsorbent. Moreover, the sonication times was effected on extraction rate. The various sonication times (1-10 minute) was used and the recoveries obtained. The best recoveries were achieved at the sonication time of $2.5 \mathrm{~min}$. Therefore, $3.0 \mathrm{~min}$ was used as the optimum time for thallium extraction in water and urine samples. After sonication, the magnetic adsorbent (Tl- $\mathrm{Fe}_{3} \mathrm{O}_{4}$ ATPyHS@GO) was collected from the liquid samples by extra magnet accessory.

\subsubsection{The adsorption capacity}

The $\mathrm{Fe}_{3} \mathrm{O}_{4}$-ATPyHS@GO adsorbent was dispersed in water samples and the extractions of thallium ions from liquid samples were followed many times and re-usage of adsorbent calculated. The results showed, the $\mathrm{Fe}_{3} \mathrm{O}_{4}$ ATPyHS@GO adsorbent can be used for 18 extraction cycles at $\mathrm{pH}$ of 5.0. The absorption capacities (AC) of the $\mathrm{Fe}_{3} \mathrm{O}_{4}$-ATPyHS@GO adsorbent depended on the BET, the function group and size of adsorbent. In batch system, $25 \mathrm{mg}$ of the $\mathrm{Fe}_{3} \mathrm{O}_{4}$-ATPyHS@ $\mathrm{GO}$ nanoparticles was used in $50 \mathrm{~mL}$ of thallium solution (5 $\left.\mathrm{mg} \mathrm{L}^{-1} ; \mathrm{ppm}\right)$ at $\mathrm{pH}$ 5.0. After 10 minutes' sonication, the AC of adsorbent calculated by F-AAS. The adsorption capacities of the $\mathrm{Fe}_{3} \mathrm{O}_{4}$-ATPyHS@GO adsorbent for $\mathrm{Tl}$ ions were obtained $137.5 \mathrm{mg} \mathrm{g}^{-1}$.

\subsubsection{Interference of coexisting ions}

The effect of main coexisting ions on thallium extraction based on the $\mathrm{Fe}_{3} \mathrm{O}_{4}$-ATPyHS@GO adsorbent was evaluated in water and urine samples by the DM- $\mu$ SPE procedure. So, the effect of various concentrations of interfering ions (1-3 ppm) was studied for $50 \mathrm{~mL}$ of water samples by proposed procedure at $\mathrm{pH}$ 5.0. The main concomitant ions in water and urine were selected and used for thallium extraction by the $\mathrm{Fe}_{3} \mathrm{O}_{4}$ ATPyHS@GO adsorbent. The results showed that the interference coexisting ions do not affect on the thallium extraction in optimum conditions (Table 2).

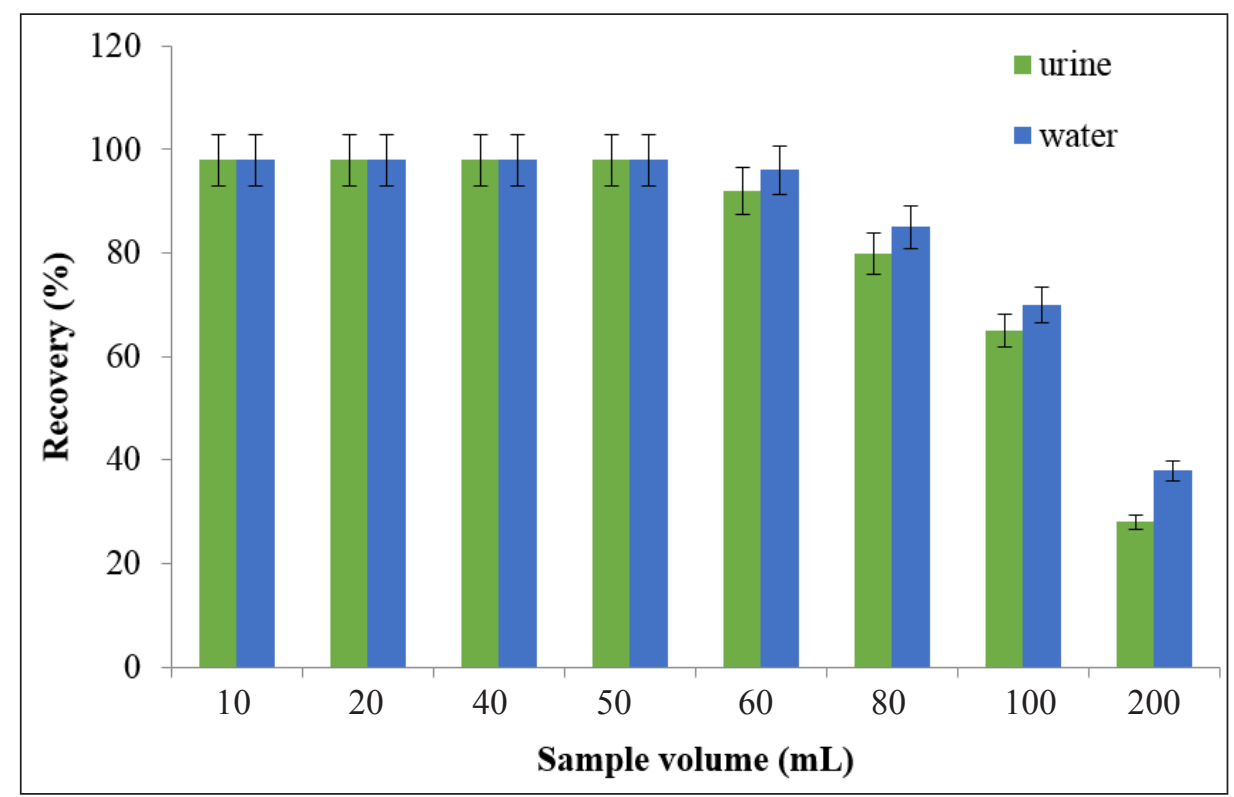

Fig.10. The effect of sample volume on thallium extraction in water and urine samples by the $\mathrm{Fe}_{3} \mathrm{O}_{4}$-ATPyHS@GO adsorbent 
Table 2. The effect of interferences ions on extraction of thallium in human urine and water samples by the DM- $\mu$ SPE procedure

\begin{tabular}{|c|c|c|c|c|}
\hline \multirow[t]{2}{*}{ Interferences ions } & $\begin{array}{c}\text { Mean ratio } \\
\left(\mathrm{C}_{\mathrm{I}} / \mathrm{C}_{\mathrm{T}(\mathrm{II})}\right)\end{array}$ & $\begin{array}{l}\text { Mean ratio } \\
\left(\mathrm{C}_{\mathrm{I}} / \mathrm{C}_{\mathrm{Tl}(\mathrm{I})}\right)\end{array}$ & Recovery (\%) & Recovery (\%) \\
\hline & Urine & Water & Urine & Water \\
\hline $\mathrm{Mo}^{2+}, \mathrm{Ni}^{2+}, \mathrm{Co}^{2+}, \mathrm{Mn}^{2+}$ & 400 & 650 & 98.1 & 97.0 \\
\hline $\mathrm{Zn}^{2+}, \mathrm{Cu}^{2+}$ & 700 & 900 & 96.5 & 98.3 \\
\hline $\mathrm{Pb}^{2+}, \mathrm{Cd}^{2+}, \mathrm{V}^{3+}, \mathrm{Cr}^{3+}$ & 550 & 700 & 98.6 & 99.2 \\
\hline $\mathrm{Br}^{-}, \mathrm{F}^{-}, \mathrm{Cl}^{-}, \mathrm{I}^{-}, \mathrm{NO}_{3}^{-}$ & 900 & 1200 & 97.9 & 98.5 \\
\hline $\mathrm{Na}^{+}, \mathrm{K}^{+}, \mathrm{Ca}^{2+}, \mathrm{Mg}^{2+}$ & 1000 & 1300 & 97.3 & 98.8 \\
\hline $\mathrm{Se}^{4+}$ & 350 & 400 & 97.1 & 97.6 \\
\hline $\mathrm{Al}^{3+}, \mathrm{Be}^{+2}$ & 600 & 600 & 97.4 & 98.7 \\
\hline $\mathrm{CO}_{3}^{2-}, \mathrm{PO}_{4}^{3-}, \mathrm{SO}_{4}^{2-}, \mathrm{NH}_{4}^{+}$ & 800 & 950 & 97.7 & 98.6 \\
\hline $\mathrm{Hg}^{2}, \mathrm{Ag}^{+}$ & 200 & 300 & 96.8 & 97.4 \\
\hline $\mathrm{Sn}^{2+}$ & 500 & 700 & 98.2 & 97.9 \\
\hline
\end{tabular}

\subsubsection{Validation in real samples}

The DM- $\mu$-SPE procedure was used for extraction and determination of thallium in water and urine samples. The validation of results for the $\mathrm{Fe}_{3} \mathrm{O}_{4}-$ ATPyHS@GO adsorbent were shown in Table 3.For validation, the real samples were spiked to different concentration of standard solutions of thallium and process continued by the DM- $\mu$-SPE procedure at
pH 5.0 (Table 3). As Table 3, the efficient extraction and high recovery for thallium ions were obtained in water and human urine samples by nanoparticles of the $\mathrm{Fe}_{3} \mathrm{O}_{4}$-ATPyHS@GO adsorbent. Moreover, the standard reference materials were prepared in water and urine samples with ICP-MS analyzer for validating of the DM- $\mu$-SPE procedure based on the $\mathrm{Fe}_{3} \mathrm{O}_{4}$-ATPyHS@GO adsorbent (Table 4).

Table 3. Validation of methodology for thallium ions in water and urine samples based on $\mathrm{Fe}_{3} \mathrm{O}_{4}$-ATPyHS@GO adsorbent by spiking of real samples

\begin{tabular}{|c|c|c|c|}
\hline Sample* & Added $\left(\mu g \mathrm{~L}^{-1}\right)$ & ${ }^{*}$ Found $\left(\mu g \mathbf{L}^{-1}\right)$ & Recovery (\%) \\
\hline \multirow{2}{*}{ a'Well water } & --- & $56.4 \pm 2.4$ & --- \\
\hline & 50 & $104.6 \pm 4.5$ & 96.4 \\
\hline \multirow{2}{*}{${ }^{\mathrm{b}}$ Wastewater } & --- & $146.6 \pm 9 / 0$ & --- \\
\hline & 150 & $294.3 \pm 13.4$ & 98.5 \\
\hline \multirow{2}{*}{ Wastewater $^{\mathrm{c}}$} & --- & $122.9 \pm 5.9$ & --- \\
\hline & 100 & $225.7 \pm 11.2$ & 102.8 \\
\hline \multirow{2}{*}{${ }^{\psi}$ Urine } & --- & $4.7 \pm 0.2$ & --- \\
\hline & 5 & $9.6 \pm 0.5$ & 98.0 \\
\hline \multirow{2}{*}{ Urine $^{\psi}$} & --- & $11.9 \pm 0.4$ & --- \\
\hline & 10 & $21.6 \pm 0.9$ & 97.0 \\
\hline & --- & $28.9 \pm 1.3$ & --- \\
\hline${ }^{\psi}$ Urine & 30 & $59.8 \pm 2.7$ & 103 \\
\hline $\begin{array}{l}\text { * Mean of three } \\
\text { aWell water pre } \\
\text { bWastewater pr } \\
\text { 'W Wastewater pr } \\
\text { 'W Urine prepare }\end{array}$ & $\begin{array}{l}\text { hinations of sampl } \\
\text { rom Varamin garc } \\
\text { from chemical fa } \\
\text { from petrochemic } \\
\text { workers from car, }\end{array}$ & $\begin{array}{l}\text { nfidence interval ( } \\
\text { aran,Iran } \\
\text { araj, Iran } \\
\text { ry, Arak, Iran } \\
\text { cal and paint factor }\end{array}$ & $\mathrm{n}=10)$ \\
\hline
\end{tabular}


Table 4. Validation of $\mathrm{D}-\mu-\mathrm{SPE}$ procedure for thallium determination in water and urine samples by ICP-MS (certified reference materials, CRM, $\mathrm{n}=10$ )

\begin{tabular}{lcccc}
\hline Sample & ICP-MS $\left(\boldsymbol{\mu} \mathbf{~ L ~ L}^{-1}\right)$ & Added & Found $^{*}\left(\boldsymbol{\mu g} \mathbf{~ L}^{-1}\right)$ & Recovery $(\%)$ \\
\hline CRM1 & $25.3 \pm 0.5$ & ---- & $24.9 \pm 1.2$ & ---- \\
& & 20.0 & $44.3 \pm 1.9$ & 97.0 \\
\hline CRM 2 & $62.7 \pm 0.7$ & ------- & 98.2 \\
\hline CRM 3 & 50.0 & $113.2 \pm 5.2$ & ---- \\
& $5.1 \pm 0.2$ & ---- & $4.8 \pm 0.2$ & 102 \\
\hline CRM 4 & 5.0 & $9.9 \pm 0.4$ & ---- \\
\end{tabular}

"Mean of three determinations of samples \pm confidence interval $(\mathrm{P}=0.95, \mathrm{n}=10)$

CRM1: Thallium concentration in Water by ICP-MS $\left(25.3 \mu \mathrm{g} \mathrm{L}^{-1}\right)$

CRM2: Thallium concentration in Wastewater by ICP-MS $\left(62.7 \mu \mathrm{g} \mathrm{L}^{-1}\right)$

CRM3: Thallium concentration in urine by ICP-MS $\left(5.1 \mu \mathrm{g} \mathrm{L}^{-1}\right)$

CRM4: Thallium concentration in urine by ICP-MS $\left(6.4 \mu \mathrm{g} \mathrm{L}^{-1}\right)$

\section{Conclusions}

A simple and reliable method was used for preconcentration, separation and determination of Tl (I) in human urine and water samples by DM- $\mu$-SPE procedure. The proposed method was developed based on magnetic $\mathrm{Fe}_{3} \mathrm{O}_{4}-$ ATPyHS@GO adsorbent at pH 5.0 without any organic chelating agent and organic solutions. The proposed method based on the $\mathrm{Fe}_{3} \mathrm{O}_{4}-$ ATPyHS@GO adsorbent can be considered for Tl extraction in liquid phase as a low cost, efficient, reusability and fast separation phase. The newly developed method was low interference, easy usage for sample preparation in human urine samples and also provides low LOD $\left(0.9 \mu \mathrm{g} \mathrm{L}^{-1}\right)$, RSD (1.8-2.1\%) values as well as good PF (50) and quantitative recoveries more than $95 \%$ for thallium extraction in water and urine human matrixes. So, the proposed method based on magnetic nanoparticles and thiol groups on the $\mathrm{Fe}_{3} \mathrm{O}_{4}$-ATPyHS@GO adsorbent can be considered as a fast sample preparation technique with low amount of adsorbent for thallium separation and determination by F-AAS.

\section{Acknowledgements}

The authors wish to thank the Department of Chemistry, Shahid Bahonar University of Kerman, Kerman, Iran and Department of Chemistry of Islamic Azad University, Kerman, Iran.

\section{References}

[1] T.S. Lin, J.O. Nriagu, Thallium in the environment, New York: Wiley, pp.31-44,1998.

[2] C. Yang, Y. Chen, P. Peng, X. Chang, C. Xie, Distribution of natural and anthropogenic thallium in the soils in an industrial pyrite slag disposing area, Sci. Total Environ., 341 (2005) 159-172.

[3] A. Vaněk, Z. Groesslova, M. Mihaljevic, Thallium contamination of soils/vegetation as affected by sphalerite weathering: a model rhizospheric experiment, J. Hazard. Mater., 283 (2015) 148-156. https://doi. org/10.1016/j. jhazmat.2014.09.018.

[4] M. Sadowska, E. Biaduń, B. KrasnodębskaOstręga, Stability of Tl(III) in the context of speciation analysis of thallium in plants, Chemosphere, 144 (2016) 1216-1223.

[5] Z. Ning, L. He, T. Xiao, L. Márton, High accumulation and subcellular distribution of thallium in green cabbage, Int. J. Phytoremed., 17 (2015)1097-1104.

[6] B. Krasnodebska-Ostrega, Tl I and Tl III presence in suspended particulate matter: speciation analysis of thallium in wastewater, Environ. Chem., 12 (2015) 374-379.

[7] P. Cvjetko, I. Cvjetko, M. Pavlica, Thallium toxicity in humans, Arch. Ind. Hyg. Toxicol., 61 (2010) 111-119. https://doi.org/ 10.2478/10004-1254-61-2010-1976. 
[8] J.M. Wallace, Kale and thallium: insights from your nutrition team. Permaculture solutions for healing, 2015.

[9] A. Lansdown, The carcinogenicity of metals: human risk through occupational and environmental exposure, Cambridge: Royal Society of Chemistry, pp. 323-330, 2013.

[10] Z. Groesslova, A. Vanek, M. Mihaljevic, V. Ettler, M. Hojdovác, T. Zádorováa, Bioaccumulation of thallium in a neutral soil as affected by solid-phase association, $\mathrm{J}$. Geochem. Explor., 159 (2015) 208-212.

[11] T. Wojtkowiak, B. Karbowska, W. Zembrzuski, M. Siepak, Z. Lukaszewski, Miocene colored waters: a new significant source of thallium in the environment, $\mathrm{J}$. Geochem. Explor., 161 (2016) 42-48. https:// doi.org/10.1016/j. gexplo.2015.09.014.

[12] F.S. Hussain, N.S. Hussain, Clinical utility of thallium-201 single photon emission computed tomography and cerebrospinal fluid epstein-barr virus detection using polymerase chain reaction in the diagnosis of AIDS-related primary central nervous system lymphoma, Cureus., 8 (2016) e606.

[13] L. Osorio-Rico A. Santamaria S. Galván-Arzate, Thallium toxicity: general issues, neurological symptoms, and neurotoxic mechanisms, Adv. Neurobiol., 18 (2017) 345-353.

[14] V. Yu, M. Juhász, A. Chiang, N. Atanaskova Mesinkovska, Alopecia and associated toxic agents: A systematic review, Skin Appendage Disord., 4 (2018) 245-260.

[15] HY. Yu, C. Chang, F. Li, Q. Wang, M. Chen, J. Zhang, Thallium in flowering cabbage and lettuce: Potential health risks for local residents of the Pearl River Delta, South China, Environ. Pollut., 241 (2018) 626-635.

[16] B. Štádlerová, M. Kolrosová, J. Dědina, S. Musil, Atomic fluorescence spectrometry for ultrasensitive determination of bismuth based on hydride generation - the role of excitation source, interference filter and flame atomizers, J. Anal. At. om., 35 (2020)
993-1002.

[17] B. Karbowska, T. Rębiś, G. Milczarek, Electrode modified by reduced graphene oxide for monitoring of total thallium in grain products, Int. J. Environ. Res. Public Health, 15 (2018) 653.

[18] L. Nyaba, T. S. Munonde, Magnetic $\mathrm{Fe}_{3} \mathrm{O}_{4} @$ $\mathrm{Mg} / \mathrm{Al}$-layered double hydroxide adsorbent for preconcentration of trace metals in water matrices, Sci. Reports, 11(2021) 2302.

[19] L. Nyaba, B. Dubazana, A. Mpupa, P. N. Nomngongo, Development of ultrasoundassisted dispersive solid-phase microextraction based on mesoporous carbon coated with silica@iron oxide nanocomposite for preconcentration of Te and $\mathrm{Tl}$ in natural water systems, Open Chem., 18 (2020) 412-425.

[20] T. Kusutaki, M. Furukawa, Preconcentration of $\mathrm{Pb}$ with aminosilanized $\mathrm{Fe}_{3} \mathrm{O}_{4}$ nanopowders in environmental water followed by electrothermal atomic absorption spectrometric determination, Chem. Eng., 3 ( 2019) 74.

[20] W.S.J. Hummers, R.E. Offeman, Preparation of graphitic oxide, J.Am. Chem. Soc., 80 (1958) 1339.

[21] S. Khodabakhshi, F. Marahel, A. Rashidi, M. Khaleghi Abbasabadi, A green synthesis of substituted coumarins using nano graphene oxide as recyclable catalyst, J. Chin. Chem. Soc., 62 (2015) 389-392.

[22] H. Shirkhanloo, M. K. Abbasabadi, F. Hosseini, A. Faghihi, Nanographene oxide modified phenyl methanethiol nanomagnetic composite for rapid separation of aluminum in wastewaters, foods, and vegetable samples by microwave dispersive magnetic micro solid-phase extraction, Food Chem., 347 (2021) 129042.

[23] M.K. Abbasabadi, A. Rashidi, S. Khodabakhshi, Benzenesulfonic acid-grafted graphene as a new and green nanoadsorbent in hydrogen sulfide removal, J. Nat. Gas Sci. Eng., 28 (2016) 87-94.

[24] M. Khaleghi-Abbasabadi, D. Azarifar, Magnetic $\mathrm{Fe}_{3} \mathrm{O}_{4}$-supported sulfonic acidfunctionalized graphene oxide $\left(\mathrm{Fe}_{3} \mathrm{O}_{4} @ \mathrm{GO}-\right.$ naphthalene- $\mathrm{SO}_{3} \mathrm{H}$ ): a novel and recyclable nanocatalyst for green one-pot synthesis, Res. Chem. Intermed., 45 (2019) 2095-2118. 